\title{
BRPKM
}

Buletin Riset Psikologi dan Kesehatan Mental

http://e-journal.unair.ac.id/index.php/BRPKM

e-ISSN: 2776-1851

ARTIKEL PENELITIAN

\section{Hubungan antara Hardiness dan Daily Spiritual Experience dengan Kesejahteraan Psikologis Mahasiswa}

\author{
SALWA SHABRINA \& NURUL HARTINI* \\ Fakultas Psikologi Universitas Airlangga
}

\begin{abstract}
ABSTRAK
Penelitian ini bertujuan untuk menguji hubungan antara hardiness dan daily spiritual experience terhadap kesejahteraan psikologis pada mahasiswa. Metode penelitian yang digunakan dalam penelitian ini adalah metode kuantitatif dengan teknik pengumpulan data menggunakan survei online. Jumlah partisipan 457 mahasiswa aktif Universitas Airlangga yang diperoleh melalui metode accidental sampling. Alat ukur yang digunakan dalam penelitian ini adalah a short hardiness scale, the daily spiritual experience scale (DSES), dan psychological well being scale. Analisis data yang dilakukan adalah uji korelasi spearman's rank dengan bantuan SPSS versi 25. Hasil dari penelitian ini menunjukkan adanya hubungan hardiness dan daily spiritual experience secara simultan dengan kesejahteraan psikologis $(\mathrm{p}=$ 0,000 atau $\mathrm{p}<0,05$ ) dengan nilai $\mathrm{R}$ sebesar 0,640. Hubungan antara hardiness dan daily spiritual experience dengan kesejahteraan psikologis bersifat positif, yang berarti bahwa apabila individu memiliki hardiness dan daily spiritual experience yang tinggi, juga didapatkan kesejahteraan psikologis yang tinggi pula.
\end{abstract}

Kata kunci: daily spiritual experience, hardiness, kesejahteraan psikologis

\section{ABSTRACT}

This study aims to examine the correlation between hardiness and daily spiritual experience toward psychological well-being of students. The research method used in this study is a quantitative method with data collection techniques using online surveys. The total participants in this study were 457 people is 457 active students of Universitas Airlangga obtained through the accidental sampling method. Data analysis carried out was Spearman's rank correlation test with the help of SPSS version 25. The results of this study showed that there was a relationship between hardiness and daily spiritual experience simultaneously with psychological well-being $(p=0.000$ or $p<0.05)$ with an R value of 0.640 . The relationship between hardiness and daily spiritual experience with psychological well-being is positive, which means that if individuals have high hardiness and daily spiritual experience, they also get high psychological well-being.

Keywords: daily spiritual experience, hardiness, psychology well-being

Buletin Penelitian Psikologi dan Kesehatan Mental (BRPKM), 2021, Vol. 1(1), 930-937

*Alamat korespondensi: Fakultas Psikologi Universitas Airlangga, Kampus B Universitas Airlangga Jalan Airlangga 4-6 Surabaya 60286. Surel: nurul.hartini@psikologi.unair.ac.id

Naskah ini merupakan naskah dengan akses terbuka dibawah ketentuan the Creative Common Attribution License (CC-BY-4.0) (http://creativecommons.org/licenses/by/4.0), sehingga penggunaan, distribusi, reproduksi dalam media apapun atas artikel ini tidak dibatasi, selama sumber aslinya disitir dengan baik. 


\section{PENDAHULUAN}

Mahasiswa adalah calon intelektual atau cendekiawan muda yang sering kali syarat dengan berbagai predikat (Sarwono, 1978). Mahasiswa bagian dari elemen masyarakat yang memiliki catatan sejarah bahwa dinamika bangsa ini tidak lepas dari peran mahasiswa. Mahasiswa biasanya menjadi harapan banyak orang untuk memberikan perubahan dengan menggunakan disiplin ilmunya dalam membantu pembangunan negara untuk menjadi lebih baik kedepannya (Rikardo, 2018). Memasuki perguruan tinggi merupakan masa transisi dari pendidikan sekolah menengah ke pendidikan tinggi. Masa transisi ini dapat menimbulkan tekanan bagi mahasiswa ditahun pertama kuliah karena dihadapkan dengan situasi dan tuntutan baru, seperti mengatasi semua masalah dan konflik (Susilowati \& Hasanat, 2015). Perubahan pola kehidupan, tuntutan akademik yang cenderung semakin berat dapat menjadi stressor bagi mahasiswa. Tanggung jawab dan tugas perkembangan yang meningkat harus dijalani pada masa ini juga dapat menjadi tekanan dan beban tersendiri bagi mahasiswa (Hidayah, 2012). Stressor yang tidak diatasi dengan baik dapat menimbulkan berbagai risiko permasalahan psikologis pada mahasiswa.

Survei di Indonesia yang telah dilakukan oleh Badan Pengembangan dan Pengkajian Keilmuan Nasional ILMPI (Ikatan Lembaga Mahasiswa Psikologi Indonesia) periode 2019-2020 menunjukkan bahwa 1.470 responden mengalami rasa cemas berkepanjangan, 1.235 responden merasakan lelah berkepanjangan tanpa penyebab yang jelas, 907 responden mengalami sedih hingga menganggu aktivitas kegiatannya, 651 responden mengaku tidak percaya diri, 23 responden tidak minat untuk berkegiatan, 19 responden merasa tertekan, 12 responden merasa dirinya tidak berguna, kemudian 168 responden mengalami permasalahan mental lainnya (ILMPI, 2020). Apabila tidak ditangani dengan baik, ketegangan psikis tersebut dapat memburuk dan mengakibatkan depresi, hingga bunuh diri.

Perubahan pola kehidupan dan meningkatnya tuntutan tanggung jawab yang dianggap sebagai tekanan dapat memicu tingginya risiko permasalahan psikologis pada mahasiswa. Individu yang merasa dalam tekanan membutuhkan strategi koping stres. Koping digunakan untuk mempertahankan stabilitas intrapsikis selama menghadapi stressor (Cushway, 1996). Individu memiliki strategi koping sesuai dengan kondisi masing-masing. Strategi koping yang baik akan mengantarkan pada kesejahteraan psikologis (Bissonnette, 1998).

Individu yang memiliki kesejahteraan psikologis yang baik dapat menjalankan berbagai perannya dengan optimal, meregulasi dirinya untuk mengatasi stres, mengatur konflik, stimulus motivasi, dan meningkatkan kepercayaan diri. Begitu pula dengan mahasiswa. Mahasiswa yang memiliki kesejahteraan psikologis yang baik akan lebih mudah untuk mencapai target-targetnya, menyelesaikan studi, dan mengimplementasikan ilmunya kepada masyarakat.

Ryff (1989) mendefinisikan kesejahteraan psikologis sebagai kondisi individu yang memiliki sikap positif terhadap diri sendiri dan orang lain, dapat membuat keputusan dan mengatur perilakunya sendiri, dapat menciptakan dan mengatur lingkungan yang kompatibel dengan kebutuhannya, memiliki tujuan hidup yang terarah, serta dapat berusaha mengeksplorasi dan mengambangkan dirinya. Berbagai konstruk psikososial yang berhubungan dengan kesejahteraan psikologis adalah status identitas, self-enhacing cognition, regulasi emosi, kepribadian, tujuan personal, nilai (value), strategi koping, proses perbandingan sosial, dan spiritualitas (Ryff \& Singer, 2008). 
Kepribadian individu akan menentukan kebiasaan individu dalam merespons stimulus kehidupan. Kepribadian hardiness merupakan susunan karakteristik kepribadian yang membuat individu menjadi lebih kuat, tahan, dan stabil dalam menghadapi stres dan mengurangi efek negatif yang dihadapi (Kobasa, 1979). Hardiness merupakan pola sikap dan strategi yang memfasilitasi perubahan kondisi stres, dari potensi keterpurukan menjadi peluang perkembangan (Maddi, 2002). Faktor kepribadian adalah variabel penting dalam mengadapi situasi yang menekan (Skomorovsky \& Sudom, 2011). Salah satu pola kepribadian yang dapat menjaga kesehatan mental individu walaupun mengalami situasi yang penuh stressor adalah hardiness (Smet, 2011). Individu yang memiliki kepribadian hardiness dapat menganggap suatu stressor sebagai suatu tantangan (Kinicki, 2005). Kepribadian hardiness memiliki peran dalam proses individu memaknai situasi yang menyebabkan timbulnya stress.

Spiritualitas dapat memberikan kontribusi positif pada kesehatan mental dan kesejahteraan psikologis individu. Daily spiritual experience adalah persepsi individu mengenai pengalaman spiritual individu yang terkait dengan hal-hal transenden dan penuh makna dalam hidup, seperti merasa dekat dengan Tuhan, memiliki rasa adanya kerinduan, mendapatkan dukungan serta kasih sayang secara transenden, dan memiliki kekaguman, kemurahan hati, serta bersyukur atas adanya Tuhan. Daily spiritual experience merupakan persepsi pada individu masing-masing dan emosi yang terkait dengan transenden pada kehidupan sehari-hari (Underwood \& Teresi, 2002; Mayoral Sánchez dkk., 2010).

Individu dengan tingkat spiritualitas yang tinggi akan memiliki keyakinan adanya kekuatan transenden yang mengatur kehidupannya. Penelitian yang dilakukan oleh Garroutte dkk. (2003) menjelaskan bahwa individu dengan spiritualitas tinggi akan lebih memaknai hidup dengan baik, dan memiliki kesejahteraan psikologi yang baik. Spiritualitas akan mempermudah individu menghadapi emosi negatif dan situasi sosial (Khashab dkk., 2015). Spiritualitas memiliki hubungan dengan tiga indikator kesejahteraan psikologis, yaitu aktualisasi diri, kebermaknaan hidup, dan pertumbuhan pribadi (Ivtzan dkk., 2013).

Mahasiswa dengan perubahan pola kehidupannya memicu adanya banyak stressor di lingkungannya. Setiap individu membutuhkan hardiness dan spiritualitas untuk menghadapi stressor. Hardiness berperan untuk memaknai stressor sebagai tantangan dan membantu individu untuk lebih tahan banting dalam menjalani kehidupan. Spiritualitas dapat mengubah perspektif individu menjadi lebih positif dipengaruhi oleh keyakinan transenden yang mengatur kehidupan. Pengalaman spiritual yang baik dapat memberikan percaya diri yang tinggi dan kekuatan bagi individu dalam menghadapi stressor. Hardiness dan daily spiritual experience dapat menuntun pada keadaan psikologis yang sejahtera.

Berdasarkan penjelasan yang telah diuraikan, peneliti ingin mengetahui lebih lanjut tentang hubungan antara hardiness dan daily spiritual experience dengan kesejahteraan psikologis pada mahasiswa. Pertanyaan dalam penelitian ini berfokus pada seberapa besar hubungan antara hardiness dan daily spiritual experience dengan kesejahteraan psikologis pada mahasiswa.

\section{Desain Penelitian}

\section{METODE}

Penelitian ini menggunakan pendekatan kuantitatif yang bertujuan untuk menghasilkan data dalam bentuk angka yang didapatkan dari hasil jawaban partisipan. Penelitian ini menggunakan metode cross sectional dengan teknik pengumpulan menggunakan teknik survei. Alat yang digunakan untuk mengumpulkan data adalah kuisioner. Penelitian survei digunakan untuk mendapatkan data responden 
dalam bentuk self-report yang mencerminkan pikiran, opini, dan perasaan individu. Pada penelitian ini, kuisioner yang digunakan untuk survei menggunakan media online. Uji validitas yang digunakan adalah validitas isi dengan bantuan professional judgement. Pengukuran reliabilitas pada instrumen penelitian ini menggunakan teknik alpha cronbach dengan bantuan software SPSS 25 for windows.

\section{Partisipan}

Partisipan dalam penelitian ini adalah mahasiswa aktif Universitas Airlangga yang berusia 17-24 tahun. Teknik sampling yang digunakan adalah accidental sampling, yaitu pengambilan sampel berdasarkan kebetulan, siapa saja yang masuk dalam kriteria sumber data dapat mengisi kuisioner yang terlah disebarkan. Sebelum mengisi survei, partisipan diminta untuk membaca pernyataan yang diberikan untuk memastikan bahwa partisipan bersedia untuk berpartisipasi dalam penelitian ini.

\section{Pengukuran}

Pengukuran hardiness dalam penelitian ini menggunakan a short hardiness scale yang dikembangkan oleh Bartone (2000, Ave \& Dc, 1999). Skala ini terdiri dari 15 pernyataan dengan menggunakan skala likert untuk pilihan jawaban ( 1 = sangat tidak sesuai, 4 = sangat sesuai) dan mencakup pertanyaan favorable dan unfavorable. Pengukuran daily spiritual experience menggunakan The Daily Spiritual Experience Scale (DSES) yang dikembangkan oleh Underwood \& Teresi (2002). Skala ini terdiri dari 16 pernyataan dengan pilihan jawaban menggunakan skala likert ( $1=$ tidak pernah, $5=$ selalu). Pengukuran kesejahteraan psikologis menggunakan psychological well being scale yang dikembangkan oleh Ryff (1989). Skala ini terdiri dari 42 pernyataan dengan menggunakan skala likert untuk pilihan jawaban (1 = sangat tidak sesuai, 4 = sangat sesuai) dan mencakup pertanyaan favorable dan unfavorable.

Validitas seluruh instrument alat ukur pada penelitian ini menggunakan validitas isi (content validity) dengan bantuan professional judgment, yaitu empat (4) dosen Fakultas Psikologi Universitas Airlangga. Pengukuran reliabilitas pada instrumen penelitian ini menggunakan teknik alpha cronbach dengan bantuan software SPSS 25 for windows. Dari uji reliabilitas tersebut, menghasilkan nilai koefisien reliabilitas alat ukur pada skala hardiness adalah 0,704, pada skala daily spiritual experience adalah 0,917, dan pada skala kesejahteraan psikologis adalah 0,883. Secara keseluruhan alat ukur yang digunakan pada penelitian ini reliabel untuk mengukur variabel-variabel penelitian.

Uji asumsi yang dilakukan yaitu uji normalitas, uji korelasi, uji heterokedastisitas, dan uji multikolinearitas. Data berdistribusi normal dan terdapat hubungan positif antara hardiness dan daily spiritual experience dengan kesejahteraan psikologis. Hasil dari uji heteroskedastisitas dan uji multikolinearitas menunjukkan tidak adanya gejala heteroskedastisitas dan tidak terjadi multikolinearitas.

\section{Analisis Data}

Analisis data yang dilakukan adalah analisis regresi berganda yang berfungsi untuk mencari hubungan dari dua atau lebih variabel bebas dan variabel terikat dengan bantuan software SPSS 25 for windows.

\section{HASIL PENELITIAN}

Hasil analisis deskriptif pada 457 partisipan menunjukkan variabel hardiness memiliki nilai $(M=42,14$; $S D=5,36)$. Pada variabel daily spiritual experience memiliki nilai $(M=112,51 ; S D=15,23)$. Hasil analisis regresi linear berganda menunjukkan bahwa hardiness dan daily spiritual experience berhubungan positif dengan kesejahteraan psikologis $(r(457)=0,640 ; \rho=0,000)$. 
$\mathrm{H}_{\mathrm{a}}$ pada penelitian ini adalah terdapat hubungan antara hardiness dan daily spiritual experience dengan kesejahteraan psikologis mahasiswa. Berdasarkan hasil uji korelasi, didapatkan bahwa hardiness dan daily spiritual experience memiliki hubungan yang positif dengan kesejahteraan psikologis. Pada variabel hardiness dan kesejahteraan psikologis memiliki hubungan yang kuat $(r(457)=0,620 ; p<0,05)$ sedangkan pada variabel daily spiritual experience memiliki hubungan yang cukup kuat $(\mathrm{r}(457)=0,412$; $\mathrm{p}<0,05)$. Hubungan pada variabel hardiness dan daily spiritual experience dengan kesejahteraan psikologis menunjukkan nilai positif yang berarti semakin tinggi hardiness dan daily spiritual experience, maka semakin tinggi pula kesejahteraan psikologis.

\section{DISKUSI}

Penelitian ini bertujuan untuk mengetahui hubungan antara hardiness dan daily spiritual experience dengan kesejahteraan psikologis mahasiswa. Menurut hasil analisis pada penelitian ini menunjukkan bahwa ada hubungan hardiness dan daily spiritual experience secara simultan dengan kesejahteraan psikologis $\left(\mathrm{H}_{\mathrm{a}}\right.$ diterima). Hubungan antara hardiness dan daily spiritual experience dengan kesejahteraan psikologis bersifat positif, yang berarti bahwa pada mahasiswa yang memiliki hardiness dan daily spiritual experience yang tinggi, juga didapatkan kesejahteraan psikologis yang tinggi pula. Hal ini sesuai dengan pernyataan bahwa kesejahteraan psikologis berhubungan dengan berbagai faktor, dua diantaranya adalah faktor kepribadian dan faktor psikososial (Ryff \& Singer, 2008). Hardiness berperan sebagai faktor kepribadian, dan spiritualitas berperan sebagai faktor psikososial. Hasil penelitian ini sesuai dengan beberapa penelitian sebelumnya yang telah dilakukan pada subjek yang berbeda, yaitu penelitian yang dilakukan oleh Skomorovsky dan Sudom (2011) yang dilakukan pada anggota militer Kanada, dan penelitian Mabruri (2017) dilakukan pada korban bencana alam di Yogyakarta, penelitian yang dilakukan oleh Garroutte, dkk (2003) orang-orang Indian Amerika, dan penelitian yang dilakukan Munthe, dkk (2017) pada anak didik pemasyarakatan di Lembaga Pemasyarakatan anak pria kelas II A Tangerang. Hal ini menunjukkan bahwa walaupun adanya perbedaan pada subjek yang diteliti, tetapi keterkaitan antara hardiness, daily spiritual experience dengan kesejahteraan psikologis memiliki hubungan yang positif.

Individu dengan kepribadian hardiness memiliki kontrol diri yang baik pada situasi yang positif maupun negatif, dan mengontrol persepsi mengenai kesulitan dalam hidup menjadi sebuah tantangan yang positif (Maddi, 2002). Selain itu, individu dengan kepribadian hardiness akan mengarahkan pada pengembangan diri dan resiliensi. Sikap-sikap tersebut akan membantu individu untuk memiliki strategi koping yang baik, sehingga dapat merespons berbagai stimulus dengan positif. Sikap positif dalam berbagai kondisi akan mengarahkan individu pada fungsi psikologis yang positif, dan mengarahkan pada keadaan kesejahteraan psikologis yang baik. Kobasa (1979) memaparkan bahwa terdapat dua tahapan proses hubungan hardiness dengan kesejahteraan psikologis. Pertama, kepribadian hardiness dapat mengubah proses penilaian kognitif individu, dan mendorong individu untuk memaknai stressor sebagai sebuah tantangan, sehingga hal tersebut akan mengurangi tekanan psikologis. Kedua, individu dengan kepribadian hardiness memiliki kemampuan untuk mengatasi masalah dengan adaptif, walaupun dalam situasi yang menekan. Hal ini disebut juga sebagai strategi koping stress oleh individu. Individu dengan strategi koping stress yang baik akan mudah berdamai dengan tekanan, sehingga dapat mencapai kesejahteraan psikologis yang baik.

Hasil uji hipotesis dalam penelitian ini juga sesuai dengan penelitian sebelumnya yang dilakukan oleh Ivtzan, dkk (2013) bahwa spiritualitas memiliki hubungan dengan tiga indikator kesejahteraan psikologis, yaitu aktualisasi diri, kebermaknaan hidup, dan pertumbuhan pribadi. Keyakinan pada 
Tuhan akan mendorong individu memiliki strategi koping yang baik (Cornah, 2006). Strategi koping yang baik dapat mengarahkan individu pada kesejahteraan psikologis yang baik (Ryff \& Singer, 2008). Tischler (2002) menjelaskan individu dengan spiritualitas akan meningkatkan kompetensi aktualisasi diri, harga diri, sikap mandiri, adaptasi yang baik, performa kinerja yang baik, empati, altruisme, sikap terbuka, dan lain sebagainya. Hasil penelitian Khashab, dkk (2015) memaparkan bahwa spiritualitas akan mempermudah individu menghadapi emosi negatif dan situasi sosial. Kompetensi-kompetensi tersebut akan mengarahkan individu pada kesejahteraan psikologis. Hal ini sesuai dengan pemaparan Underwood \& Teresi (2002), yaitu daily spiritual experience dapat memberikan kontribusi positif pada kesehatan mental dan kesejahteraan psikologis individu. Individu dengan spiritualitas tinggi akan memiliki keyakinan adanya kekuatan transenden yang mengatur kehidupannya, sehingga individu tersebut akan lebih mudah untuk memaknai hidup dengan baik dan mencapai kesejahteraan psikologis yang baik.

\section{SIMPULAN}

Penelitian ini dilakukan untuk menguji adanya hubungan yang signifikan antara hardiness dan daily spiritual experience dengan kesejahteraan psikologis pada mahasiswa. Hasil penelitian ini menunjukkan adanya hubungan yang signifikan dari hardiness dan daily spiritual experience dengan kesejahteraan psikologis pada mahasiswa, sehingga $\mathrm{H}_{\mathrm{a}}$ diterima. Penelitian mengenai hardiness dan daily spiritual experience secara simultan dengan kesejahteraan psikologis masih belum banyak dilakukan. Penelitianpenelitian sebelumnya kebanyakan hanya meneliti salah satu variabel, yaitu hardiness atau daily spiritual experience dengan kesejahteraan psikologis. Diharapkan hasil penelitian ini dapat memberikan tambahan pengetahuan dan dapat dijadikan bahan kajian lebih lanjut untuk penelitian selanjutnya. Bagi penelitian selanjutnya, disarakan untuk menggunakan metode kualitatif agar dapat memperkaya data dan mengembangkan teori yang lebih kuat.

\section{UCAPAN TERIMAKASIH}

Terima kasih kepada Allah SWT, keluarga, dan teman-teman yang telah mendukung dan membantu penulis selama proses penelitian. Terima kasih juga kepada pihak-pihak yang turut berkontribusi dalam penelitian ini. Terima kasih kepada seluruh dosen pengajar dan staf di Fakultas Psikologi Universitas Airlangga, partisipan pada penelitian ini, dan seluruh pihak yang tidak dapat disebutkan satu-persatu.

\section{DEKLARASI POTENSI TERJADINYA KONFLIK KEPENTINGAN}

Salwa Shabrina dan Nurul Hartini tidak bekerja, menjadi konsultan, memiliki saham, atau menerima dana dari perusahaan atau organisasi manapun yang mungkin akan mengambil untung dari diterbitkannya naskah ini.

\section{PUSTAKA ACUAN}

Ave, D., \& Dc, W. (1999). Report Number Agency Report Number. Robotics, 298(in 1992), 1992-1993.

Bissonnette, M. (1998). Optimism, Hardiness, and Resiliency : A Review of the Literature Prepared for the Child and Family Partnership Project. Review Literature And Arts Of The Americas, 1-22. 
Cornah, D. (2006). The impact of spirituality on mental health: A review of the literature. Mental Health Foundation.

Cushway, B. (1996). Human Resource Management. Elex Media Komputindo.

Garroutte, E. M., Goldberg, J., Beals, J., Herrell, R., Manson, S. M., Crow, C. B., Buchwald, D., Chambers, B., Christensen, M., Dillard, D., DuBray, K., Espinoza, P., Fleming, C., Frederick, A. W., Gone, J., Gurley, D., Jervis, L., Jim, S., Kaufman, C., ... Yazzie, L. (2003). Spirituality and attempted suicide among American Indians. Social Science and Medicine, 56(7), 1571-1579. https://doi.org/10.1016/S0277-9536(02)00157-0

Hidayah, D. N. (2012). Persepsi Mahasiswa Tentang Harapan Orang Tua Terhadap Pendidikan dan Ketakutan akan Kegagalan. Educational Psychology Journal, 1(1), 62-67.

ILMPI. (2020). Layanan Kesehatan Mental di Lingkungan Kampus: Urgensi dan Solusi.

Ivtzan, I., Chan, C. P. L., Gardner, H. E., \& Prashar, K. (2013). Linking Religion and Spirituality with Psychological Well-being: Examining Self-actualisation, Meaning in Life, and Personal Growth Initiative. Journal of Religion and Health, 52(3), 915-929. https://doi.org/10.1007/s10943-0119540-2

Khashab, A. S., Khashab, A. M., Mohammadi, M. R., Zarabipour, H., \& Malekpour, V. (2015). Predicting dimensions of psychological well being based on religious orientations and spirituality: An investigation into a causal model. Iranian Journal of Psychiatry, 10(1), 50-55.

Kinicki, R. K. \& A. (2005). Perilaku Organisasi Edisi 5 (A. B. E. Suandy (ed.); 5 th ed.). Salemba Empat.

Kobasa, S. C. (1979). Stressful life events, personality, and health: an inquiry into hardiness. Journal If Personality, 37(1), 1-11.

Mabruri, M. I. (2017). Hubungan Antara Kepribadian Tangguh Dan Religiusitas Dengan Kesejahteraan Psikologis Pada Korban Bencana Alam Di Yogyakarta. Intuisi : Jurnal Psikologi Ilmiah, 1(2), 109117.

Maddi, S. R. (2002). The story of hardiness: Twenty years of theorizing, research, and practice. Consulting Psychology Journal: Practice and Research, 54(3), 173-185. https://doi.org/10.1037/1061-4087.54.3.175

Mayoral Sánchez, E. G., Laca Arocena, F. a, \& Mejía Ceballos, J. C. (2010). Daily spiritual experience in Basques and Mexicans: a quantitative study. Journal of Transpersonal Research, 2(1), 10-25.

Munthe, Maslihah, \& Chotidjah. (2017). Hubungan spiritualitas dan psychological well-being pada anak didik pemasyarakatan di lembaga pemasyarakatan anak pria kelas II A Tangerang. Jurnal Psikologi Klinis Indonesia, 1(1), 53-65.

Rikardo, Y. (2018). Peran Mahasiswa, Pemuda Sebagai Agent OfChange.

Ryff, C. D. (1989). Happiness Is Everything, or Is It? Explorations on the Meaning of Psychological Well 
Being. Journal of Personality and Social Psychology, 57(6), 1069-1081.

Ryff, C. D., \& Singer, B. H. (2008). Know thyself and become what you are: A eudaimonic approach to psychological well-being. Journal of Happiness Studies, 9(1), 13-39. https://doi.org/10.1007/s10902-006-9019-0

Sarwono, S. W. (1978). Perbedaan antara Pemimpin dan Aktivis dalam Gerakan Protes Mahasiswa. Bulan Bintang.

Skomorovsky, A., \& Sudom, K. A. (2011). Psychological well-being of canadian forces officer candidates: The unique roles of hardiness and personality. Military Medicine, 176(4), 389-396. https://doi.org/10.7205/MILMED-D-10-00359

Smet, B. (2011). Psikologi Kesehatan. PT. Grasindo.

Susilowati, T. G., \& Hasanat, N. U. (2015). Pengaruh Terapi Menulis Pengalaman Emosional Terhadap Penurunan Depresi pada Mahasiswa Tahun Pertama. Jurnal Psikologi, 38(1), 92 - 107-107. https://doi.org/10.22146/jpsi.7669

Tischler, L., Biberman, J., \& Mckeage, R. (2002). Linking emotional intelligence, spirituality and workplace performance:Definitions, models and ideas for research. Journal of Managerial Psychology, 17(3), 203-218. https://doi.org/10.1108/02683940210423114

Underwood, L. G., \& Teresi, J. A. (2002). The Daily Spiritual Experience Scale: Development, theoretical description, reliability, exploratory factor analysis, and preliminary construct validity using healthrelated data. Annals of Behavioral Medicine, 24(1), 22-33. https://doi.org/10.1207/S15324796ABM2401_04 